\title{
Riding the Iron Horse into the Future of Regulation: The Contribution of Charles Francis Adams Jr
}

\author{
Timothy J Fogarty ${ }^{*}$
}

Department of Accountancy, Weatherhead School of Management, Case Western Reserve University, USA

\begin{abstract}
Charles F. Adams Jr. instigated the creation of the Massachusetts Railway Commission in 1869. This freestanding body sought to oversee the overall the operation of railroads in that state. This paper suggests that many of our current ideas about the process and content of commercial regulation were developed in the historical context.
\end{abstract}

Keywords: Railroad; Economy; Accounting

\section{INTRODUCTION}

Studies in accounting history are predicated on the assumption that contemporary issues benefit from a more complete understanding made possible only by an analysis of origins. In other words better knowledge about the past provides a needed prologue to the appreciation of the present.

This paper takes up this gauntlet by highlighting the work of Charles Adams and the Massachusetts Railroad Commission in the decades following the Civil War in the United States. The assertion of this work is that the seeds of modern accounting and business regulation were planted by the man at this time. To some extent, these origins would revise the conventional placement of the genesis in the turn of the $20^{\text {th }}$ century's formation of the Interstate Commerce Commission (ICC) and the efforts of the Theodore Roosevelt administration. Although no contribution to our current way of thinking is so original or unprecedented to not owe equivalent debts to those that came before, the work of Adams merits additional attention in the regulation literature.

This paper is organized to first establish the historical facts, a retelling of which would be news to many. The two longest sections of the paper will detail the multifaceted contributions to the process of regulation and to the content of regulation. Throughout, parallels to the modern uses and debates will be identified. This paper concludes with a summary assessment of the place of Adams as a forerunner of modern regulatory thought.

\section{THE HISTORICAL CONTEXT}

Although much has been written about the role of the railroad in the industrialization of the United States [1] a brief acknowledgement of the uniqueness of that moment is necessary. The dawning of a system whereby goods produced in one area could be sold in another held such obvious promise that the emergent industry's capitalization was sudden and unprecedented [2]. America's first real big business offered unique economic problems most notably, virtually unlimited economics of scale scrambled traditional ideas about competition. In addition, the fever to raise capital dispatched the traditional ideas that investors could ground trust in their personal knowledge of responsible individuals. In an era, resistant to both monopoly and public ownership, the practice of capitalism needed to evolve. Railroads were the harbinger and the facilitator of the legendarily sharp practices that would soon facilitate the rise of the robber barons. Ironically, the shenanigans that led to great fortunes tended to be obscured by the great commercial progress that new technology made possible.

Adams, a member of the illustrious New England family that included two presidents eschewed a career in the law for the opportunity to pave at then a relatively uncharted course as a regulator. Awed by the prospect of the railroad and mindful of its public interest implications, Adams instigated the formation of the Massachusetts Railway Commission in 1869. Well before the federal government would play any significant part, this body headed by Adams would be a role model for other states confronting the problem of the railroad. In reflection of the fractured power of the individual states, Adams organized the Saratoga Convention of 1879 that convened many state relations and advocated common solutions. This event would serve as a template for subsequent efforts by the ICC, which in turn would regularize the chaotic business of railroading.

Throughout his career, Charles Adams was at the fulcrum of weighty issues. He was called upon to consider the fairness of

${ }^{*}$ Correspondence to: Timothy J Fogarty, Department of Accountancy, Weatherhead School of Management, Case Western Reserve University, USA, Tel: 216 368 3938; E-mail: tjf@case.edu

Received: December 23, 2018; Accepted: January 21, 2019; Published: January 28, 2019

Citation: Fogarty TJ (2019) Riding the Iron Horse into the Future of Regulation: The Contribution of Charles Francis Adams Jr. Int J Account Res 7:193. doi: 10.35248/2472-114X.19.7.193

Copyright: (C) 2019 Fogarty TJ. This is an open-access article distributed under the terms of the Creative Commons Attribution License, which permits unrestricted use, distribution, and reproduction in any medium, provided the original author and source are credited. 
prices when markets did not operate as expected. He struggled with the dissemination of proprietary information in the name of a higher good. He recognized that the instinct of private enterprise for unfettered growth may prove destructive. Through his writings on various subjects, we find that Adams was a man ahead of his time. Many of the issues on his plate continue to bedevil us today.

\section{THE PROCESS OF REGULATION}

\section{Use of a scientific method}

The task of regulation is a complex one. Charles Adams however did not succumb to the enormity of the job. He instead believed effective regulation would result from the application of a scientific approach. The idea that an economic reality existed, and could be found, motivated Adams to relentlessly gather data, and to pursue more. This data offered little other than the opportunity that created trial and error approaches that were recognized as provisional, especially as more data became available.

One might assert that regulation can be frustrated by the lack of sufficient relevant facts. Adams was game for the challenge of applying a systematic approach to what began as a negligible set of materials. He persevered in his efforts despite the recognition that measurement will never be perfect. Valuation was particularly important to the capital-intensive railroads in the era that focused on the balance sheet. In fact, Adams only began the examination of the many valuation questions that would have to be faced. Nonetheless, he should be credited with a material extension of the belief that the detection of patterns in quantitative information would enable a more perfect control of the social and physical worlds that existed at the time.

A critical element of the scientific method is to eschew precommitments to a resolution. It cannot be good science if one "knows" the answer before doing the experiment. Adams was unique for his times in that he had a willingness to reverse that which had been done and pursue a course close to its opposite to see what would happen. Adams wanted results that delivered the knowledge that would effectuate control, but he had little ideological orientations about its direction.

Traces of a continued commitment to what would be called as scientific method continue today. Most vividly, Shapiro outlines a set of presuppositions about standard setting that should guide the search for truth and realism [3]. Less generally, Martin et al. describes how an auditor might approach fair value measurement [4]. For the entire community, the scientific approach taken by Adams now lies more deeply embedded in our appreciation. Nonetheless, deficiencies in technical knowledge diminished the quality of standard setting debates [5,6] indicating the need for more experiments even if one was to concede gradual improvement through time.

For the most part, Adams struggled to impose a new science upon the raw data. Now that this has been done for some time, the effort experiences resistance. Some suggest that either external frames of reference or internal criteria inconsistency will doom this science $[7,8]$. Others suggest that accounting never could be approached in this manner, preferring to look more directly at the discreet ways that accounting is practiced $[9,10]$. Still others assert that accounting standard setting is constrained by interest or by the gamesmanship of participants [11,12]. Thus, Adams would find a fresh set of critics to those he encountered when attempting a then novel process.

\section{The structure of regulation}

The importance of the commission form of regulation devised by Adams is difficult to overestimate. The form that regulation takes is highly consequential to its outcomes and its acceptability. In this instance, the commission was able to slowly accumulate an evidentiary basis for regulation and be able to nimbly respond to a fluid situation presented by a large but infant industry. The commission had no unilateral power per se, existing only by virtue of its blessing from those that did (the state legislature) and acting with the confidence that their recommendations would have persuasive weight. Railroads and those affected by them subscribed to what seemed to be a broad power delegation to fact-find and to focus endless energy upon the conduct of railroading.

The commission represented the confluence of necessary inputs for effective regulation. First, the commission would assemble the requisite expertise from diverse sources. Adams was not atypical of the times, as a self-taught railroad expert who had defected from the study of law. Second, the commission had a budget to spend in the furtherance of their objective. Part of this money could be spent on salaries paid to those who had the time and talent to devote to its work. Third, the commission was a vehicle to demand the attention of the public. With its activities good fodder for the newspapers of the day, the commission's actions were newsworthy - McCraw called Adam's approach to regulation "the Sunshine Commission" since the purpose of the commission was to expose the corrupt business practices in hopes that, once in the open, the businessmen would be shamed in mending their ways. It was in this vein that he wrote A Chapter of Erie. Miranti considered Adams to be an authority on the speculative financing of the 1860 s, who thought that the full publicity of accounts could protect the public from the depredations of dishonest market operators [13]. This spotlighted a public discourse that would demand a certain level of rationality from participants and ceteris paribus discourage uncooperative behavior. Any individual above could not garner this level of public opinion based support. Fourth, the commission had agenda control. Established to deal with the multidimensional problems associated with the railroads, the commission's discretion was not bound to particular topics. Perhaps railroads accepted the work of the commission as the lesser evil contrasted to what other "trouble" it could stir.

The success of the Commission in no small part can be attributed to the way that its implicit authority was exercised by Adams. Mindful of the need to maintain the cooperation of the railroads, Adams avoided the temptation to dwell upon responsibility for past misdeeds. Although it would have been easy to pinpoint responsibility for deviations, Adams purposefully oriented the Commission toward the future. Particularly with regard to accidents, the priority of the commission became process improvements that would reduce danger going forward. Adams preferred a low-key approach by eschewing the inflammatory rhetoric that the passions of the day would have made easy. Adams did not want to provoke tests of strength against the railroads, instead reiterating their common interest in a long-term cooperation. This approach of political astuteness gave participants what they needed to stay at the table, but it may have deflected the commission from the larger and more difficult issues.

The persistent focus of the Massachusetts Commission was the collection of information. Adams brought to the commission a strong bias towards the notion that power resided in data. Part 
of this related to using information to deter rumor and myth. In this regard, information had to be set free. Compelled from the railroads, the Commission served as a dissemination vehicle. Adams also believed that information properly collected and organized would reveal unknown truths that would enhance efficiency and effectiveness. That very little breakthrough insight actually resulted from this effort is not the regulatory point. No doubt, demand for information by the Commission inspired railroads to produce more information and to use it for managerial purposes. That information from other railroads was not available may have also stimulated comparative reflection among the regulated entities.

The Massachusetts Commission broke new ground regarding its design. First and most importantly the body was assiduously independent. Adams typified its membership with no previous connections with railroads, unions, or interest groups that conflicted with railroads. Second, the Commission operated in a much less formal way than other typical legal bodies of that day. Minimizing the rigors of due process, the Commission took a "get down to business" approach to substance. Third, the Commission consisted of a much smaller number of people than was usual for this time. In this way, the Commission avoided the bloated process that stymied action and minimized the formation of factions. Fourth, the Commission undertook on its own initiative the production of an annual report. This document attested to the accountability of the body to the public. Its contents are highly factual, avoiding advocacy of any particular future result.

The ideas pioneered by Adams on how regulation should be designed find many reverberations in today's world. The design of the FASB would seem to be a beneficiary of some of these insights in that it is a small body, operating in the sunshine and devoting much effort to information gathering $[10,14]$. More fundamentally, the idea of a private sector body performing a public function [15] also is part of this legacy. Understanding economic consequence without focusing upon their primacy [16] also shows the continued thin line walked by regulators when regulate support is critical [17].

The current world is marked by better theory including those that focus on the conceptual nature and value of sequential information [18]. We also have a stronger appreciation for the continued efforts of the regulatory body to remain in the good graces of those that empowered [19]. Towards this end we take lessons from failed regulatory bodies. The first of these bodies seemed quite prescient about some of the levers of success that still operate today.

\section{The proper nature of financial regulation}

The story of Charles Adams and the emergence of the railroads as big business necessitate an assessment of the general contours of business regulation. The railroads brought to America much that was good, but also much that was bad. The regulatory philosophy needed to magnify the former and minimize the latter, in a way that would encourage manageable growth. A blind faith in competition and its invisible hand, which would have led to a laisse-faire response, did not seem to be a viable option. In fact, a regulation that protected the young industry from self-destruction was as important as one that would protect the public.

Adams believed that regulation had to be efficient. The companies should not be exposed to heavy compliance costs. How much a rule would cost to implement was taken into the deliberation process. Even in the absence of such costs, Adams did not believe in regulation for the sake of regulation. Adams preferred tightly drawn rules to far-reaching standards. In this way policy could coexist with continued entrepreneurial innovation.

This minimalistic regulatory presumption allowed the voluntaristic spirit to be nurtured. Bolstered by the ability to get expert opinion on the record, Adams was at his best when he created incentives for railroads to impose constraints upon themselves. He was able to get companies to go beyond required disclosures. Although it would be some time before companies would follow suit in the unregulated environment [20,21], a notable precedent in a highvisibility industry had been created. Even if such behavior was a proactive attempt to avoid a more coercive regulatory infrastructure, it illustrates the power of the right sort of nudge.

Some debate exists over whether accounting regulations continue to follow the "less is more" philosophy of Charles Adams. Although the official position of the FASB is to improve quality without overburdening corporate entities [15], a long-standing critique is that standards have become too complex, too theoretical, and too expensive without increases in value $[22,23]$. Others see a strong accounting policy presence need to counterweigh managerial tendencies to distort [24] and to make progress in social welfare [25]. In other words, conflict over accounting continues so that he, who regulates least, just doesn't get much done.

\section{Benchmarking as the objective of regulation}

The insufficiency of information available to the railroad regulators that Adams found in Massachusetts was problematic for several reasons. Obviously, that which should occur cannot be known without a clear sense of that which is occurring. The arbitrary and imprecise rules that did compel information left wide latitude embedded in the reports that were received.

Adams understood that good information from even some railroads would facilitate the statistic comparison with other railroads. That Adams appreciated the value of benchmarking best practices lies most apparent in his observations regarding the taxation of railroads in Europe. Unfortunately benchmarking remained quite aspirational for Adams in the US. The data proved of too variable quality for this to be ventured.

The ability to benchmark is deeply embedded in regulatory practices today. Gathering information for the explicit purpose of comparison is taken for granted as a purpose, perhaps because the variability in its production is manageable. Lev discusses the theoretic value of regulation favoring the less informed when information is asymmetrically distributed. In practice, harmonization projections spread critical conceptions of accountability in ways that Adams would have supported [26,27].

\section{The place of fairness}

Market-based solutions can be harsh ones. Agents with the upper hand in transactions can exploit their position, extracting rents above and beyond equilibrium. Regulation is the obvious response, as victims attempt to level the playing field through the political process. Reasonable people disagree about the results when fairness is the major reason for a regulatory response.

The availability of railroad shipping tended to scramble the product markets of the day. The array of good from distant places increased, making it quite difficult for sellers not to tap into the greater movement prospects offered by railroad shipping. Suddenly railroads had the power to influence winners and losers in terms 
of the shipping expenses that would be passed on to downstream consumers. Railroads also had enormous leverage in labor markets and in financial circles. Thus, there was no shortage of victims crying foul over railroad behavior.

A heavy-handed regulatory approach would have steered the power of the state against the railroads. Sudden development in the private sector had out-flanked the usual steadying hand of the public sector. Many expected the formation of the Commission to be an opportunity for government to again be a powerful force. Under Adams however, this body did not render forceful fairness arguments. The deployment of expertise took the dialogue in other directions. The Commission did not dwell upon distributive consequences. Instead the focus was finding the truth that could be the basis of establishing forward-looking policy. Fairness, if it was involved, tended to be soft-pedaled into resolutions.

The approach taken by Adams and his fellow commissioners harmonize with that followed in the modern bureaucracies of government regulation. A line is drawn between the task of elected officials and others, with the enactment of social policy left to the former. For example, the FASB does not officially weigh adverse impact because such would thrust the body into a policy making where fairness is important [16]. Fairness is essentially a moral argument requiring a judgment from a particular perspective [28]. At best, accounting standards should be acceptable [29], which is quite distinct from fair. Another line is drawn between process and outcomes where the former need be fair [30].

How much fairness enters regulation could be rigorously debated. Liberal jurisprudence does not shy from creating social policy, and thus fairness was essentially evaluated as far back as the early cases involving the ICC. Fairness also is culturally sensitive and worms its way into the very meaning of words used in the regulatory process [31].

\section{Jurisdiction control}

Before big business came to the US, local government could adequately address the conflicts among the citizenry. State governments existed to provide a modicum of consistency, but only on an as needed basis. In matters of domestic commerce, the federal government was largely irrelevant. The advent of the railroads challenged existing notions of proper jurisdictional control.

Railroads traversed great distances therefore making local control ineffective. In that they also passed across state borders, state governments could only partially influence their operation. Jurisdictional limitations compounded the larger issue that state legislative bodies lacked sufficient expertise to know what to do about the railroads. Notwithstanding the commerce clause of the US Constitution, the federal government was even more unable to respond either by virtue of inadequate resources or political will.

With his advocacy for the Massachusetts Commission, Adams brought for the inception of matrix governance. Here special purpose entities of very specific jurisdiction could be formed on a relatively permanent basis, and exist in conjunction with traditional geographically defined entities. This formulation would allow for the progressive accumulation of expertise and the ongoing focus to provide routine oversight. As Adams recognized that the state legislature could not act with the requisite intelligence, the way for a standing commission was clear.
The work toward the Saratoga Convention was largely a reflection of the need for a larger jurisdictional footprint. An inter-state version of the Massachusetts Commission would not suffer the constraints and would be able to address the larger phenomenon put forth by the railroads of the day. Although material progress of this nature would not be made in Adams' time, a good idea whose time would come was extended. The Saratoga Convention premise would eventually be baked into the ICC as soon as the federal government was ready to step up to this sort of solution. Adams would have probably preferred some sort of multi-state accord to one that would eventually federalize jurisdictional control.

Much water has passed over the bridge since Charles Adams held forth. The root cause of the problem of limited jurisdiction would be played out on many fronts as the federal government gradually preempted state regulatory control. Technology destroys the importance of geography, as we see today as the regulation of the Internet takes shape. The crisis caused by the Great Depression and the Second World War would be needed to bring about the fully administered bureaucracies of today. The Saratoga Convention inspired by Charles Adams was a harbinger, albeit on a very humble scale, of what would come.

\section{THE CONTENT OF REGULATION}

\section{The pursuit of the public interest}

At his core, Charles Adams wished to be a reformer. He believed that his calling was as an ombudsman who would mediate this economic conflict that the railroads created. Hailing from such a patrician family, such an aspiration was either a curiosity to others and psychologically difficult to admit. Adams sought to work within the system, believing that opposed interests could be harmonized through reasoned dialogue. Specifically, the science of economics, to which Adams subscribed, provided a field from which the objective facts, once seen, could forge agreement. Adams saw his role as the person who argued for a transcendent public obligation charged to private enterprise. This implied stewardship that this subtly suggests was as controversial in this time as it is now. For Adams, the railroad wielded great power that could be harmful to other interests unless tempered with the ideology of a public welfare.

Adams influenced the powers by which the public interest could be pursued. First, reform had to be based on deep knowledge of the phenomenon. Thus nothing could be expected from legislative bodies. Reform could only occur after a deep commitment to measurement had been made. Reformers like Adams knew the slow and relatively modest public interest concessions were all that could be hoped for in the situation.

In Adam's view, any reform that was possible had to exploit market forces rather than attempt to contradict them. Toward that objective, Adams had an intuitive respect for the transformative power of new technology. The railroad presented an extreme case because of the tendency toward geographical, "natural" monopolies that limited the balance that competition could bring. Adams also appreciated the multiplier effect that efficient railroad service could mean for the country.

To many, public interest based reform necessarily suggests naked conflict. Adams however remained steadfast in the belief that discord of this sort could be avoided. For example, Adams was not a supporter of labor unions but was willing to work with these 
groups. Adams believed that the best resolutions were grounded in revealed self-interest, and not dogmatically imposed political edits. Conflict was inevitable but it did not, and should not, require power to be exerted.

The legacy of Adams can be observed in the accounting standard setting process. A large plurality of support exists on a normative level for public interest considerations in the process [32]. Lev argues that equity can serve as operational criteria for public interest concerns [26]. In fact, the consensus position acknowledges a deep link between accounting and the social welfare [8]. At the same time, hope is unlimited that reliable and relevant standards faithful to the economics of transactions can be produced, with financial consequences an acceptable result. Adams would be pleased with the broad acceptance of the infusion of professional values into standard setting, especially when such values suggest fidelity to the measurement ethic. Adams would have also looked with favor with how standard setting has made its peace with its political environment [12].

On the other hand, other current developments would have surprised or dismayed Adams. The public interest has itself become a rhetorical strategy. Sometimes this tactic is exerted by the standard setting body to define its work and marginalize alternatives [33]. Great legislation that has changed the course of accounting in the name of the public interest often has had hidden agendas $[34,35]$. Adams did not anticipate that historical cost accounting had limitations that could not be overcome [29]. Furthermore, the commercialization of accounting has created more dimensionality and complexity for standard setting [36], than Adams could have foreseen. Stewardship as a general motif has not achieved much traction, tending to dismiss any transcendent public service goal, following advice by Paton [37].

\section{The regulation of competition}

The development of the railroad changed the substantive meaning of economic competition in the US. For the first time, narrow geographic lamentations for choices faced by agents could be transcending by the movement of goods. Most market participants soon recognized the usual superiority of railroad transportation, an advantage that only grew as the network of connections was built out.

The transcendence of the local also brought unprecedented problems. Some of these, such as safe operation presented a high volume of tribulation without major conceptual difficulties. Others were enveloped in puzzles that had not been previously confronted. Most centrally, competition heretofore the central mechanism of the invisible hand of capitalism could not operate well. The infrastructure required usually meant that only one railroad could service any two points. Those that arrived first could exclude others and exploit their advantages with customers. The situation called into question the laissez-faire presumption that dominated the government section of that day. The capital accumulation needs of this new industry also formed a new class of potential victims. What rights investors had vis-à-vis management existed as a mostly legally untested field.

Adams discovered that the balance between the interested parties would be sufficiently contested that caution would be required. The operation of an ongoing commission created a forum for the airing of grievances, the testing of solutions, and perhaps most importantly fact finding. Although great compromises that refined the nature of property rights in the age of the day/ technological breakthroughs were few, Adams can be credited with not capitulating before the daunting task. Adams normalized the acceptance of reasonable compliance costs and made conceptual progress against the idea that people with property should be given unfettered freedom to use that property.

Adams' efforts may have formed a necessary precedent for the famous "trust-busting" successes of the Theodore Roosevelt administration a few decades later. Continued problems with railroads' exertion of unilateral privileges were also at the center of these actions. Since then antitrust law has evolved to grant the federal government power to identify anti-competitive actions (Sherman Act) and to pre-empt merger proposals (Clayton Act). Although little of this has been linear or apolitical, competition is now approached in a more nuanced way with some forms seen as substitutes for others. The important point remains that the need to regulate competition no longer is questioned.

\section{The anti-fraud objective}

Very few would associate Charles Adams with the fight against fraudulent practices and deceptive behavior. Adams was not part of any enforcement machinery, nor was he a muckraker who specialized in investigative journalism. Adams focused on normal operations which tended to presume the honorable intentions of participants.

Fraud has always been with us, and therefore should be considered an implicit component of the regulatory agenda. The potential for the reality of fraud justifies governmental intervention into private sector markets. The interaction between buyer and seller is governed by caveat emptor as the parties contract to allocate unknown risks. However, when results are unacceptable, in part due to disproportionate bargaining power and widely asymmetrical information, market results call out to be altered. Although regulation does not have to be a reactive response to actual fraud the prospects for such heightens the regulatory moment.

Adams was an early and strong proponent of the proverbial disinfectant quality of operating in the sunshine. This ethos casts a vote against fraud in that deception either needs or is facilitated by covert behavior. Fraudulent activity by companies also tended to require the falsification of accounting or operational reports. Companies able to claim proprietary reasons for not disclosing these records are better able to cover their tracks. As a strong and unwavering voice for an always expanding scope of information as part of the public record, Adams effectively fought fraud in a proactive sense.

The public quality of business and accounting regulation has long been accepted as the preferred modus operendi. Deliberations and even conversations tend to be "on the record" to the extent that parties not present can request transcripts and other preservations of these events. "Sunshine" laws became de rigor in the 1970 s perhaps in reaction to the Watergate scandal. The Freedom of Information Act has been very useful to many that could otherwise be adversely affected by governmental activity. Accounting regulations enacted by the FASB tend to have complete packages of deliberation. Regulation FD made it necessary for corporate officials to avoid private disclosures to analysts. The advance of the "regulated by agency" regime means that less and less of which that occurs in corporations is truly secret. Nonetheless, corporations vigorously oppose forced disclosure of plans and forward looking information 
in their MD\&A commentary. Adams would have celebrated this general victory of what at this time no doubt seemed exceptional and different.

\section{Towards standardized reporting}

Perhaps more than any other single accomplishment, Charles Adams is credited with major progress in the long march toward comparability in business reporting. His advocacy of this objective again outstripped actual attainment, but this would leave much to subsequent eras.

Requesting information and getting it in a useable form are two different achievements. Following self-devised arbitrary protocols, railroads assembled, compiled, and reported information as they pleased. A wide latitude of acceptability existed in an era when outsiders felt privileged to be receiving any information at all. Little was known about the production of this information and its internal reliability. Variation in form could be idiosyncratic, but it also could be strategic. This prospect naturally triggered skepticism among its readers. However, a broad appreciation did not exist at this time for the importance of format to substance. For example, a mountain of highly detailed operational results produced by the railroads could be greatly undermined by the lack of a common year end.

Much about railroads argued against any progress toward standardized information packages. Railroads, operating in different geographic areas, encountered different obstacles that drove operational costs. Other contingencies were induced by the nature of the clientele that railroads serviced. Every railroad conceived of themselves as sui generis, rather than as a unit of an industry. Whatever prospect existed for regulation began with the knowledge that could be obtained from standard reports. On an aspirational basis, these hopes ranged as far as for a system of taxation that was simple, proportionate, ascertainable, and collectible.

Many current debates continue to hinge upon the trajectory that Adams encouraged with the railroads. A series of events all point in the same direction of continuing to expand the total amount of information available to external parties, from the Jenkins Report of the 1990s (AICPA, 1994) to the "Big Data" push of today. Working with the existing scope of financial reporting, the gradual movement toward XBRL without convincing evidence of benefits illustrates how standardization has become a relatively uncontroversial objective. Meanwhile, behavioral studies have attempted to understand the influence of report structure on internal and external parties [38]. The worldwide harmonization of accounting standards tends to be accepted as a theoretically desirable objective, despite considerable implementation disagreements [39].

The apparent victory of standardization has triggered reactions and resistances. More flexibility is often hailed as desirable, be it based on the size of the reporting unit (Big GAAP vs. Small GAAP) [40] or by those that prefer a judgment-intensive conceptual accounting to one of bright-line rules. Some fear that the pressures toward standardization will stifle progress toward better approaches [41] or delimiting judgment that prevents the victory of form over substance [28]. Paton reminds us that varying circumstances call for varying accounting [37]. On a more macro-scale, others have called for new ways of thinking about accountability itself [27] and potentially re-imagining the standard-setting process as an unnecessary monopoly [42].

\section{Rate regulation}

Consenting to any inroads against its exclusive right of private parties to run their affairs presented difficulties for the railroads. However, their ultimate prerogative was the establishment of the rates charged to customers wanting to ship their products. Like several other concerns, rate regulation was not attempted by Adams in the Massachusetts Commission. Nonetheless the prospect of such was a distinct spectre.

Given certain costs, the rates set for customers determined profitability. Profits were central to investor confidence and to the ability of managers to perpetuate their positions. In normal industries price is held within reason by the elasticity of demand. However, once the superiority of shipping by rail was recognized, excessive rents could be extracted by monopoly pricing by railroads. Thus the idea of establishing an equitable price would serve as a Holy Grail of regulatory attempt.

Adams realized that rate regulation could never occur without good information about costs. The major advances in cost accounting lie in the distant future, so this objective would consume all of Adams' talents. The cost recovery of initial capital outlays that we now recognize as depreciation would prove to be bedevilment. Knowing rate regulation would prove highly controversial; Adams denounced bold steps in the direction such as flat rates. Nor did Adams wish to be dragged into conversations that would attempt to calibrate cargo comparisons. Adams conceded how sensitive pricing was and was willing to leave its subjectivities to railroad management. Affected individuals had plenty of other concerns about the railroads that Adams was content to prioritize. Adams did appreciate that rate regulation would be necessary to the uniform valuation that could clear the way for an apportioned tax. True progress on rates needed the power of federal legislation that would appear for the ICC.

Broad recognition that the public interest demanded some control over pricing took many decades to develop. The designation of activities that provided very essential services as utilities preceded the establishment of commissions that would define costs that could be recovered through highly regulated prices. Although these companies remained in the public sector, this comprehensive regulation would relegate their appeal to investors that wanted a low risk steady return. Conversations along these same lines occur today with regards to the regulation of Internet access. Such requires much more concentrated power and political consensus than Adams could have ever dreamed possible.

\section{Focus on the investor}

The activity of Charles Adams and that of the Massachusetts Commission represented one of the first systematic efforts to protect the interest of the investing community. For the large part, these investors were bondholders who had lent the funds that initially allowed the railroad to be built and then satisfactorily operated. The size of this undertaking, combined with the widespread belief that railroading possessed "can't miss" profitability horizons, magnified the distance between the investor class and the railroads operations. Such a situation placed an extra premium on reliable and sufficient information dissemination, usually in the form of cost accounting data. Unfortunately deception in these records was common and difficult to detect.

The idea of stewardship needed to be reinforced in an era where no 
tradition of voluntary annual reports existed. If management felt accountable to those that had risked their fortunes on the success of the railroads, they lacked any means to assure these individuals that the risks they faced were within reasonable bounds. Investors only knew that all was well when they experienced the returns to which they were entitled. Investors of the day were not seen as possessing information rights in part because their stake was perceived to be highly unliquid in secondary markets. Even if investors were given operating information, they usually lack a context to judge its implications.

By compelling information and explanation, the Commission sought nothing less than to make railroad management better. Given the precarious position of investors, nothing short of higher levels of accountability would make a difference. The Commission was not explicit in this effort, but no one could have missed the point that making decisions that were evidence-based would be in everyone's interests. In that the information given to the Commission was also reported to the public, investors now possessed some means of comparing the fortunes of the line that they had trusted with their money with others. Although this context was both limited and somewhat speculative given the information at hand, it compared favorably with nothing at all.

Protecting investors never proceeded so far as to be tantamount with "swindle" investigations. The assumption in place was that management was honorable, and that all efforts would be made to repay investors and creditors. The forward-looking tendency suggests that better accounting would suffice to avoid investor complaints.

The centrality of the information needs of investors has gained great acceptance since Adams' days. That financial regulation's primary purpose is to add to the confidence of investors [43] would approximate an unchallenged proposition. So much effort aligns in this direction that the financial statement audit might have lost its unique value. As the capital markets have evolved, and differentiated impacts exist for different types of investors, we have reason to wonder if standard setting has erred in the effort to protect investors, to the neglect of more fundamental stewardship [24]. On another front, user needs is so firmly entrenched despite considerable mechanical vagueness [44] and rhetorical posturing [45].

The victory of user needs underlines the foray of accounting standard setting with fair value territory. A deeper question about the conceptual basis upon which such user needs rests [46]. Here one might be well advised to distinguish actual decisions that need good measures from decision theories [47]. Secondary effects on non-users should also not be ignored.

\section{The role of accounting}

In the mid-nineteenth century, not much accounting expertise existed in the US. Critical lines had not yet been drawn that would separate accounting information from operational/business data. Desire to answer the questions that accounting now addresses existed. However, the means to achieve answers that found broad agreement would prove difficult.

Adams began by realizing that the railroads had invested in accounting expertise, such as it was. The job proved not to be one in which accounting had to be imposed on the railroads. Adams introduced experts from outside the railroads in the process of attaining compromise.
Given the state of accounting, only minor victories were possible for Adams. He did deliver in consent to use the accrual method to value liabilities, and agreements regarding the calculation of rates of return. In a general way, Adams sought a principlesinfused accounting that usually eluded his efforts. It was an era of great variation in practice and only small inroads were possible. Accounting of this era tended to facilitate the results that companies wanted.

The passage of time has seen great investments in proper accounting. Although a coherent conceptual framework proved elusive, the variation in practice is not nearly as broad as it once was. The audit process induces considerable discipline. This progress has not prevented parties from rather systematic earnings management. Parties still make arguments for accounting methods that convey strategic advantage $[25,41]$. As parties become more conscious of accounting consequences, transactions have become more complex, thereby still challenging those that pursue ideal accounting. The debate between rules-based and a principlesbased rages on with professionalism arguments [36], evidence of opportunistic behavior at the margin, and a rejection of the question [48]. Adams possessed sufficiently robust thinking so as to side with all three lines.

\section{DISCUSSION}

\section{What Adams never imagined}

Every person is a product of their times and Charles Adams is no exception. What people do reflects the institutions and worldviews of that period. However, the measure of the man can also be seen in counter distinction to perspectives revealed by subsequent times.

In a way, Adams' belief in and pursuit of accounting truth seems almost quaint today. In retrospect, we now understand that accounting is too important to be left in the hands of accountants. In other words, while Adams appreciated the political aspects of what he worked upon, he did not realize that they could subvert the pursuit of good accounting. As also discovered retroactively by the APB, accounting problems are not mostly technical [12]. Adams would have been surprised at the effort by private interest groups and their lobbyists seeking advantage, in part by "spinning" a very pliable truth [11].

Adams sought a means to capture the economic reality that existed within the operation of the railroads. We now have been shown that accounting constructs its own reality in the contexts in which it operates [49]. In that people so fundamentally believe in accounting classifications and constructs in the modern world that they change their behavior in accordance with them, the world that Adams sought to create may have been too successfully wrought. In other words, accounting cannot be a neutral measure but instead is one likely to set unintended consequences in motion.

In that Adams and the Commission sought to be a body that caused the production of good information that would be available to the public, one usually thinks of him as a progenitor of the regulatory community.

However, one now sees most of this work handled in the private sector world of auditing. This line of development becomes compromised when one observes that public accounting firms have not been content to play the role of neutral arbiter of good accounting between corporate preparers and accounting users. In 
many ways the foray into lucrative consulting practices have aligned them with the former to protect future revenue streams. As such, they add dimensionality to the production of good accounting.

\section{CONCLUSION}

Adams, mostly through his early work with the Massachusetts Commission, was positioned at a unique important moment in time. The railroads as America's first Big Business had arrived in America and would change the country in permanent and not entirely desirable ways. Adams helped to formulate the outlines of a regulatory response that would contain the seeds of much that we believe to be appropriate today about the negotiation between public and private spheres.

One reason that Charles Francis Adams Jr. has not received due recognition as a forefather of regulation is that his tangible achievements are not large. His name is not associated with a great decision or a turning point resolution. However, he did initiate a process that has been much replicated for more than a century and a half. Adams also should be credited by having the ideas about regulation that are likely to normalize a highly conflictual circumstance.

Much has happened since the time of Adams. Railroading in the US is still a commercially critical operation since where goods originate and where they can be sold still need to be aligned. In densely populated corridors, people commute and travel using trains. Derailments and other accidents are still first page news. However, media attention has migrated more routines to new technologies and new forms of business. The railroad remains geographically grounded in an era more sensitized to that which connects globally. Nonetheless, we need to respect our past and to discover that which we have always known. And when discussing regulation that brings us back to ideas generated by Adams and his somewhat novel idea of publicity-the commission represented public opinion: to listen, investigate and report; with "the board of commissioners set up as a sort of lens by means of which the otherwise scattered rays of public opinion could be concentrated to a focus and brought to bear upon a given point [50].

\section{REFERENCES}

1. Chandler AD. Strategy and Structure: Chapters in the History of the Industrial Enterprise (Cambridge, Mass., 1962). The Visible Hand: The Managerial Revolution in American Business. 1977;17-24.

2. McCraw T. Prophets of Regulation: Charles Francis Adams, Louis D. Brandeis, James M. Landis, Alfred E. Kahn. Belknap Press. 1984.

3. Shapiro BP. Objectivity, relativism, and truth in external financial reporting: What's really at stake in the disputes? Accounting, Organizations and Society. 1997;22:165-185.

4. Martin RD, Rich JS, Wilks TJ. Auditing fair value measurements: A synthesis of relevant research. Accounting Horizons. 2006;20:287-303.

5. Gerboth D. The Accounting Game, Accounting Horizons, December. 1987;96-99.

6. Gerboth D. The Conceptual Framework: Not Definitions but Professional Values, Accounting Horizons. 1987;1:1-8.

7. Anthony R. We Don`t Have the Accounting Concepts We Need. Harvard Business Review. 1987;75-83.

8. Solomons D. Making Accounting Policy (Oxford University Press). 1986a.
9. Thomas A. Toward a Value-Neutral Positive Science of Accounting, Journal of Business, Finance and Accounting. 1981;8:549-572.

10. Trueblood R. Ten years of the APB: one practitioner's appraisal. Journal of Accountancy. 1970;129:61-65.

11. Tinker A. Theories of the State and the State of Accounting: Economic Reductionism and Political Voluntarism in Accounting Regulation Theory. Journal of Accounting and Public Policy. 1984;3:55-74.

12. Gerboth D. Research, Intuition and Politics in Accounting Theory, Accounting Review. 1973;48:475-482.

13. Miranti PJ. The mind's eye of reform: The ICC's Bureau of Statistics and Accounts and a vision of regulation, 1887-1940. The Business History Review. 1989;63:469-509.

14. Kulczycky M, Harrington D, Horoszko P. External Forces Distort Accounting Practice. Savings Institutions. 1986;107:9-16.

15. Beresford DR. What's Right with the FASB. Journal of Accountancy. 1990;169:81-85.

16. Mosso D. Public policy and the FASB: As seen by one of its board members. Bottomline, December. 1987.

17. Feroz EH. Group participation in governmental accounting standards setting: A cluster analysis. Public Administration Quarterly. 1986;9:470-485.

18. Demski JS, FitzGerald SA, Ijiri Y, Ijiri Y, Lin H. Quantum information and accounting information: Exploring conceptual applications of topology. Journal of Accounting and Public Policy. 2009;28:133-147.

19. Dyckman T. Credibility and the Formulation of Accounting Standards under the F.A.S.B. Journal of Accounting Literature. 1988;7:1-30.

20. Carduff K, Fogarty T. Men of steel: Voluntary accounting information disclosure in the first third of the twentieth century at US Steel Corporation. Research in Accounting Regulation. 2014;26:196-203.

21. Fogarty T. Structural-functionalism and financial accounting: Standard setting in the US. Critical perspectives on accounting. 1994;5:205-226.

22. Chandler CH. A businessman's view of the standard-setting process. Financial Executive. 1990;6:46-51.

23. Juvenal DSF. Sir Chairman David Tweedie International Accounting Standards Board-IASB Cannon Street, 30-London 9 March Subject: Exposure Draft of Hedge Accounting. 2011.

24. Benston GJ, Carmichael DR, Jamal K, Demski JS, Laux B, et al. The FASB's Conceptual Framework for Financial Reporting: A Critical Analysis by the American Accounting Association's Financial Accounting Standards Committee. 2006.

25. Daley L, Tranter T. Limitations on the Value of the Conceptual Framework in Evaluating Extant Accounting Standards, Accounting Horizons. 1990;4:15-24.

26. Lev B. Toward a theory of equitable and efficient accounting policy. Accounting Review. 1988;63:1-22.

27. Lehman G. A critical perspective on the harmonisation of accounting in a globalising world. Critical Perspectives on Accounting. 2005; 16:975-992.

28. Merino B, Coe T. Uniformity in Accounting: A Historical Perspective. Journal of Accountancy. 1978 146:62-69.

29. Solomons D. The social impact of accounting, FE: The Magazine for Financial Executives. 1986b;2:20-23.

30. Brooks M. FASB: Agent for Change in a Conservative World. Management Accounting (UK). 1985 63:24-25.

31. Nobes C. The development of national and transnational regulation on the scope of consolidation. Accounting, Auditing and Accountability Journal. 2014;27:995-1025. 
32. Miller PB, Flegm EH. Should the FASB Be Neutral or Responsive? Journal of Accountancy. 1990 169:35.

33. Young JJ. Constructing, persuading and silencing: the rhetoric of accounting standards. Accounting, Organizations and Society. 2003;28:621-638.

34. Merino BD, Neimark MD. Disclosure Regulation and Public Policy: A Sociohistorical Reappraisal. Journal of Accounting and Public Policy. 1982;1:33-57.

35. Bealing W, Dirsmith M, Fogarty T. An Institutional Account of the Birth of the Securities and Exchange Commission Accounting, Organizations and Society. 1996;21:317-338.

36. Wyatt AR. Professionalism in standard-setting. The CPA Journal. 1988;58:20-23.

37. Paton W. Earmarks of a Profession-and the APB. Journal of Accountancy. 1971;131:37-45.

38. Rowe C. The effect of accounting report structure and team structure on performance in cross-functional teams. The Accounting Review. 2004;79:1153-1180.

39. Sunder S. Uniform financial reporting standards: Reconsidering the top-down push. Yale ICF Working. 2007; Paper No. 07-11.

40. Knutson DL, Wickmann H. The accounting standards overload problem for American small businesses. Journal of Business Finance \& Accounting. 1985;12:387-397.

41. Guthrie K, Irving JH, Sokolowsky J. Accounting choice and the fair value option. Accounting Horizons. 2011;25:487-510.
42. Sunder S. Regulatory competition among accounting standards within and across international boundaries. Journal of Accounting and Public Policy. 2002;21:219-234.

43. Bailey A. An Appraisal of Current Events in Accounting StandardSetting, speech given at the AAA Doctoral Student Consortium, Lake Tahoe, June. 2007.

44. Rutherford B. The True And Fair View Doctrine: A Search for Explication. Journal of Business, Finance and Accounting. 1985; 12:483-494.

45. Young JJ. Making up users. Accounting, Organizations and Society. 2006;31:579-600

46. Hitz JM. The decision usefulness of fair value accounting-a theoretical perspective. European Accounting Review. 2007;16:323-362.

47. Sterling R. On Theory Construction and Verification. The Accounting Review. 1970;45:444-457.

48. Cunningham LA. Prescription to retire the rhetoric of principlesbased systems in corporate law, securities regulation, and accounting, Vandervilt. Law. Review. 2007;60:1409-1449.

49. Hopwood A, Burchell S, Chubb C. Value added accounting and national economic policy in A. Hopwood and P. Miller eds., Accounting as Social and Institutional Practice (Cambridge UK: Cambridge University Press). 1994.

50. Adams CF. Railroads: Their Origin and Problems. G. P. Putnam's Sons. 1878. 